\title{
Gastronomik Ürün Çeşitlendirme Kapsamında Veganlar ve Çölyak Hastaları İçin Ürün Geliştirme: Kazandibi
}

\author{
Dr. Öğr. Üyesi Aykut Şi̇MŞEK \\ Kastamonu Üniversitesi \\ asimsek@kastamonu.edu.tr \\ https://orcid.org/0000-0002-3317-2330 \\ Arş. Gör. Enes GÜLEÇ \\ Kastamonu Üniversitesi \\ enesgulec@kastamonu.edu.tr \\ https://orcid.org/0000-0002-6684-6522 \\ Arş. Gör. Sevim USTA \\ Sakarya Uygulamalı Bilimler Üniversitesi \\ sevimusta@subu.edu.tr \\ https://orcid.org/0000-0002-7918-6383 \\ https://doi.org/10.37847/tdtad.698196
}

\section{Özet}

Bu çalışmada veganların ve çölyak hastalarının tüketebileceği bir tarifin geliştirilmesi ve geliştirilen tarifin toplu üretim alanlarında da satışa sunulması amaçlanmaktadır. Bu amaç doğrultusunda Türk mutfağına ait kazandibi tatlısının hem evde yapılabilecek hem de ticari amaçlı üretilebilecek şekilde standart reçetesi hazırlanmıştır. Bunun için de Hindistan cevizi sütü ve pirinç unu kullanılarak kazandibi tatlısı veganların ve çölyak hastalarının tüketebileceği 4 farklı formda hazırlanmıştır. Değerlendirme sürecinde de iki aşamalı olarak deneysel araştırma yöntemi kullanılmıştır. Öncelikle eğitimli panelistler tarafından söz konusu reçeteler ile hazırlanan ürünün duyusal analizi yapılarak en çok beğenilen form tespit edilmiştir. İkinci aşamada ise en çok beğenilen formun standart reçete haline getirilerek yeni bir ürün geliştirilmesi için tüketiciler üzerinde duyusal analiz yapılmıştır. Sonuç olarak, geliştirilen reçete hem panelistler hem de tüketiciler tarafından beğenilmiştir. Ayrıca tüketicilerin söz konusu reçete ile hazırlanan ürünü satın alma konusunda istekli olduklarını ifade etmişlerdir.

Anahtar Kelimeler: Vegan, Çölyak, Tatl1, Kazandibi, Duyusal Analiz.

\section{Product Development the Vegans and Celiac Patients within the Scope of Gastronomic Product Diversion: Kazandibi}

\begin{abstract}
In this study, it is aimed to develop a recipe that vegans and celiac patients can consume and to offer the this recipe for sale in mass production areas. For this purpose, the recipe of the Turkish dessert, the kazandibi dessert, has been prepared so that it can be produced both at home and for commercial purposes. For this purpose, it is prepared in 4 different forms that can be consumed by vegans and celiac patients by using coconut milk and rice flour. In the evaluation process, experimental research method was used in two stages. First of all, sensory analysis of these recipes was made by trained panelists and the most liked form was determined. In the second stage, sensory analysis was carried
\end{abstract}


out on consumers to develop a new product by making the most liked form a standard description. As a result, the recipe was liked by both panelists and consumers. They also stated that consumers were eager to purchase the recipe in question.

Keywords: Vegan, Celiac, Dessert, Kazandibi, Sensory Analysis.

\section{Giriş}

Beslenme alışkanlıklarının tarihten bugüne kadar çok hızlı değişmesiyle birlikte evrime uğradığını söylemek mümkündür (Vatan ve Türkbaş, 2018). Çağdaş uygarlığın oluşumu için temel dönüm noktasının, kuşkusuz tarıma ve dolayısıyla yerleşik yaşama geçiş olduğu söylenebilir (Yıldız, 2018). Ateşin bulunmasıyla birlikte de et tüketimi artmış ve bu şekilde beslenme alışkanlığına kolay uyum sağlanmıştır (Vatan ve Türkbaş, 2018). İnsan ve doğa arasında kurulan ilişkinin beslenmeye yansıması yalnızca et tüketimiyle sınırlı olmamıştır (Tekten-Aksürmeli ve Beşirli, 2019).

Avc1-toplayıcı toplumdan tarıma geçilmesiyle birlikte yerleşik yaşama geçiş sağlanmıştır ve protein ağırlıklı beslenme biçimi yerini daha çok karbonhidrat ağırlık beslenmeye bırakmıştır. Dolayısıyla beslenme alışkanlıklarında değişiklikler yaşanmış ve insan bünyesinin bu duruma uyum sağlaması kolay olmamıştır. Çünkü beslenme şekilleri insanları biçimlendirmiş ve beraberinde de toplumları şekillendirmiştir. Yani beslenme alışkanlıklarına bağlı olarak kalıtsal hastalıklar da beraberinde gelmiştir (Yıldız, 2018). Toplumların sahip olduğu farklı beslenme alışkanlıkları da tarihsel süreç içerisinde çeşitlilik göstermeye başlamıştır. Bu durum geleneklere, göreneklere, dini inanışlara bağlı olarak çeşitlendiği gibi, insanların doğa ile olan ilişkisine göre de çeşitlilik gösterebilmektedir (Dilek, 2018). Ancak günümüzde birçok farklı beslenme alışkanlıkları ortaya çıkmıştır. Bu alışkanlıklar çölyak hastalığı gibi bireylerin tükettikleri ürünlerden kaynaklanan rahatsızlıklar sonucunda ortaya çıkarken, veganlık gibi bir yaşam biçimi şeklinde de oluşabilmektedir.

Vejetaryenlik, yumurta, süt ürünleri, bal gibi hayvansal gıdaların tercihe bağlı olarak tüketildiği ya da hiç tüketilmediği, tamamen bitkisel kaynaklı beslenme biçimidir. Veganlık ise vejetaryen beslenme biçiminin yanında, her türlü hayvansal ürünlerin kullanımına karşı olmak (yün, deri, ipek vb.) ve hayvanlar üzerinde deney uygulanmış ürünlerin tüketimine ve bu ürünlerinkullanımına karşı olma felsefesidir (www.tvd.org.tr). Bazı bireyler sağlıklı olmak adına vegan beslenmeyi seçerken, bazıları ise hayvanlara saygı gösterilmesi gerektiğini düşündüğünden bu beslenme alışkanlığına geçiş yapmıştır (Yılmaz, 2018). Veganlar, her türlü et ve et ürününün yanı sıra süt, peynir, bal gibi hayvansal gıdalarla beslenmeyi reddeder ve ipek, yün, deri gibi hayvansal menşeili ürünleri kullanmazlar (www.tvd.org.tr). İlk vegan topluluğu 1944'te ortaya çıkmıştır ve başlangıçta ön yargılara sebep olmuştur. Ancak vegan beslenme sonucunda bazı hastalıkların riskinin azalmasıla birlikte bu ön yargı da azalmıș ve duyulan ilgi günümüze kadar artarak devam etmiştir (Yılmaz, 2018).

Çölyak hastalığ1, genetik olarak yatkın bireylerde tahıllara ve tahıl ürünlerinde bulunan glütenekarş1 duyarlılık sonucu ortaya çıkan bir hastalıktır (Yanal ve Özdil, 2014). Kronik bir hastalık olmasına rağmen tedavisi mümkün olan bir hastalıktır ve tedavisi glüten içeren besinlerin diyetten çıkarılmasıyla mümkündür (www.medicalpark.com.tr).

Vejeteryan ve vegan beslenme, sadece Türkiye'de değil dünya genelinde de önemli bir yayılım gösteren beslenme eğilimidir. Ancak bu yayılıma rağmen söz konusu eğilime yönelik ürünlerin yeterli düzeyde bulunmadığını söylemek mümkündür. Her ne kadar gerekçe olarak pazar payının küçük olmas1 öne sürülse de söz konusu pazar her geçen gün büyümektedir (Albayrak, 2017). Dünya genelindeki vegan sayılarına bakıldığında Türkiye Vegan ve Vejetaryenler Derneği verilerine göre Avrupa'daki vegan bireylerin sayısının arttığı görülmektedir. Avusturya, Belçika, Fransa, Almanya gibi ülkelerde nüfusun \% 8'ine kadar sayının ulaştığını söylemek mümkündür. Ancak Türkiye'de 
vegan sayısıyla ilgili bir istatistik mevcut değildir. Özellikle büyük şehirlerde vegan kişi sayısının arttı̆̆ı iddia edilebilir. Çünkü İstanbul, Ankara, İzmir ve Diyarbakır'da yalnızca vegan/vejetaryen menülerin sunulduğu restoranların açılması bu anlamda dikkat çeken bir husustur. Ayrıca büyük şehirlerde vegan yemek seçenekleri sunan mekanların sayısının hızla arttığı görülmektedir (TektenAksürmeli ve Beşirli, 2019).

Vejetaryen ve vegan beslenmeyi tercih eden birey sayısının dünya genelinde 600 milyondan fazla olduğu tahmin edilmektedir. Katı vegan beslenmeyi uygulamayan, sadece hayvansal gidalardan uzak durmaya çalışanların sayısı eklendiğinde ise bir milyardan fazla tüketicinin oluşturduğu büyük bir pazarın varlığının turizm endüstrileri üzerinde önemli bir rol oynadığı söylenebilmektedir (Vatan ve Türkbaş, 2018). Çünkü veganlık ve buna bağlı deneyimler felsefe, sosyoloji, gastronomi ve turizm gibi disiplinlerin çalışma alanlarına giren konuları içerir (Tekten-Aksürmeli ve Beşirli, 2019).

Çölyak hastalarına yönelik ürün geliştirme çalışmalarına bakıldığında çoğunlukla glütensiz unlarla ekmek, kek, bisküvi, erişte, pide, kurabiye gibi ürünlerin geliştirilerek duyusal analizlerinin yapıldığı görülmektedir (Ergin, 2011; Seferoğlu, 2012; Savtekin, 2014; Olgun, Başçiftçi, Ayter ve Aydın, 2017; Durlu-Özkaya, Akbulut ve Tulga, 2017). Veganlara yönelik yapılan çalışmalarda ise yiyecek içecek işletmelerinde vegan seçeneklerinin sinırlı sayıda olduğu (Vatan ve Türkbaş, 2018), dolayısıyla ürün yelpazesinin genişletilmesi gerektiği (Dilek, 2018) ifade edilmektedir. Bu durumlardan hareketle vegan beslenme modeli ve çölyak hastaları için alanda yeni ürünlerin geliştirilmesi ihtiyacı doğmuştur.

Bu çalışmada Türk mutfak kültürüne ait tatlı çeşitlerinden veganların ve çölyak hastalarının tüketebileceği tatlıların az olması sebebiyle bir ürün seçilmiştir. Seçilen ürün, Türk mutfağının klasik tatlıları arasında yer alan sütlü tatlı kazandibi olarak belirlenmiştir. Bu kapsamda da veganların ve çölyak hastalarının tüketebileceği formatta kazandibi hazırlamıştır. Hindistan cevizi sütü ve pirinç unu kullanılarak yapılan kazandibi tatlısının duyusal analizini yapmak için örneklem grubu olarak eğitimli panelistler ve tüketiciler üzerinde testler yapılmış ve tüketicilerin kazandibini beğenme düzeylerini ortaya çıkarmak hedeflenmiştir. Ayrıca örneklem grubunun en çok beğendiği form standart reçete haline getirilerek yeni ürün geliştirilmiştir.

\section{Yöntem}

Bu çalışmada veganların ve çölyak hastalarının tüketebileceği bir standart reçetenin geliştirilmesi ve geliştirilen reçetenin toplu üretim alanlarında da satışa sunulması amaçlanmaktadır. $\mathrm{Bu}$ amaç doğrultusunda Türk mutfağına ait kazandibi tatlısının hem evde yapılabilecek hem de ticari amaçlı üretilebilecek şekilde standart reçetesi hazırlanmıştır. Bunun için de Hindistan cevizi sütü ve pirinç unu kullanılarak kazandibi tatlısı veganların ve çölyak hastalarının tüketebileceği 4 farklı formda hazırlanmıştır. Değerlendirme sürecinde de iki aşamalı olarak deneysel araştırma yöntemi kullanılmıştır. Öncelikle eğitimli panelistler tarafından söz konusu reçetelerin duyusal analizi yapılarak en çok beğenilen form tespit edilmiştir. İkinci aşamada ise en çok beğenilen formun standart reçete haline getirilerek yeni bir ürün geliştirilmesi için tüketiciler üzerinde duyusal analiz yapılmıştır. Araştırma örneklem grubunu duyusal analiz eğitimi almış panelistler (8) ve tüketiciler (85) oluşturmaktadır. Duyusal analiz için hazırlanmış olan anket üç bölümden oluşmaktadır. Birinci bölümde demografik özelliklere yer verilmiştir. İkinci bölümde ise 5'li beğeni ölçeği şeklinde ürün görünümü, kokusu, dokusu, lezzeti ve genel beğeni düzeyi sorulmuştur. Üçüncü bölümde ise tadılan ürünle dışarıda herhangi bir işletmede karşılaştıklarında satın alma niyetleri sorulmuştur.

\section{Duyusal Analiz Değerlendirmesi}

Çalışmada toplamda 4 ürün üretilmiştir ve duyusal analiz iki grup şeklinde gerçekleştirilmiştir. Birinci grup eğitimli panelistlerden $(n=8)$ oluşurken, ikinci grup tüketicilerden $(n=85)$ oluşmuştur. 
Eğitimli panelistler, duyusal analiz konusunda eğitim almış olan Gastronomi ve Mutfak Sanatları bölümünde yüksek lisans eğitimi alan kişilerden oluşmaktadır. Araştırma kapsamında 4 farklı kazandibi hazırlanmıştır. Panelistlerden doldurmaları istenen duyusal analiz ölçeğinde 1: "çok kötü", 2: "kötü”, 3: “orta”, 4: “iyi”, 5: “çok iyi” şeklinde 5'li beğeni ölçeği kullanılmıştır. Ölçekte ürünlerle ilgili görünüm, koku, doku, lezzet olarak dört bölüm yer almaktadır. Görünümle ilgili olarak renk, şekil, ilk izlenim ve karamelizasyon rengi gibi kriterler, dokuyla ilgili homojenlik ve ağızda sıvanan yapının olup olmadığı, kokuyla ilgili koku beğenisi ve belirgin koku olup olmadığı, lezzetle ilgili tatlılık oranları, karamelizasyon oranı ve lezzet düzeyi, kıvamıyla ilgili ise çok sulu veya çok kıvamlı olmasına yönelik sorular sorulmuştur. 4 ürün tadım eğitimi almış olan panelistler tarafindan duyusal analizi yapılmış olup çıkan sonuçlara istinaden ortaya çıkan son ürün için tüketici tadım anketi uygulanmıştır. Araştırmada ikinci grubu oluşturan kişiler tüketicilerdir. Araştırma kapsamında oluşturulmuş ürünün tüketiciler tarafindan duyusal analizi yapılmış ve hazırlanan tüketici duyusal analiz ölçeğini doldurmaları istenmiştir.

\section{Reçetelerin Oluşturulması}

Araştırma kapsamında üretilen ürünler veganlık tüketebilecekleri malzemelerle hazırlanmıştır. Ayrıca çölyak hastalarının glütensiz ürün tükettikleri göz önünde bulundurularak reçetede buğday unu yerine pirinç unu kullanılmıştır. Üretilen ürünlerin kodlarına, gramajlarına ve içeriklerine ilişkin bilgiler Tablo 1'de gösterilmektedir.

Tablo 1. Çalışmada Üretilen Ürünlere Ait Kodlar ve Kullanılan Malzemeler

\begin{tabular}{|c|c|}
\hline Ürün Kodu & Kullanılan Malzemeler \\
\hline $\mathrm{T}$ & $\begin{array}{l}\text { Hindistan cevizi sütü } 500 \text { gr, } 1 \text { adet damla sakızı, } 250 \text { gr incir kurusu, } 60 \text { gr chia tohumu, } \\
50 \text { gr mısır nişastası, } 50 \text { gr sübye }\end{array}$ \\
\hline T1 & Hindistan cevizi sütü 500 gr, 1 adet damla sakızı, $125 \mathrm{gr} \mathrm{şeker,} 70$ gr pirinç unu \\
\hline T2 & Hindistan cevizi sütü 500 gr, 1 adet damla sakızı, 100 gr şeker, 70 gr pirinç unu \\
\hline T3 & $\begin{array}{l}\text { Hindistan cevizi sütü } 1 \text { lt, } 1 \text { adet damla sakızı, } 200 \text { gr şeker, } 65 \text { gr mısır nişastası, } 65 \text { gr } \\
\text { pirinç unu }\end{array}$ \\
\hline T4 & $\begin{array}{l}\text { Hindistan cevizi sütü } 1 \text { lt, } 1 \text { adet damla sakızı, } 200 \text { gr şeker, } 40 \text { gr mısır nişastası, } 60 \text { gr } \\
\text { pirinç unu }\end{array}$ \\
\hline
\end{tabular}

Araştırma kapsamında hazırlanan ürünler; T, T1, T2, T3 ve T4 şeklinde kodlanmıştır. Yapılan çalışmanın ilk ürünü $\mathrm{T}$ olarak belirtilmiştir. Orijinal reçeteden yola çıkılarak hazırlanan $\mathrm{T}$ tarifinde şeker kullanılmamış, yerine tatlandırıcı olması amacıyla içeriğinde şeker oranı yüksek olan kuru incir tercih edilmiştir. Şekerin kullanılmaması sebebiyle diyabet hastaları için de geliştirilen bir ürün olması amaçlanmıştır. Ancak kuru incirin, tatlının rengini koyulaştırdığı ve algılanabilir şeker düzeyini düşürdüğü için üründe şekerin kullanılmasına karar verilmiştir. Ürünün orijinalinde kullanılan sübye aynı şekilde kullanılmak istenilmiştir. Bununla birlikte içerisine chia tohumu eklenmiş ve elde edilen sonuçlara göre homojen bir karışım elde edilememiştir. Ürünün tekstürel yapısına bakıldığında koyu ve kırılgan bir yapı elde edilmiştir fakat bu istenilmeyen bir özelliktir. Bundan dolayı T ürününün değiştirilmesine karar verilmiştir.

Ekleme ve çıkarmalar sonucunda belirlenen reçetenin yapımını ise şöyledir: Damla sakızı dışında bütün malzemeler derin bir tencereye alınıp pürüzsüz olana kadar çırpma teliyle karıştırılmıştır. Ocağa alınan karışım kısık ateşte sürekli karıştırılarak kıvam alana kadar pişirilmiştir. Damla sakızı en son ilave edilmiştir. Daha sonra yakma işlemi için tepsi ocağa alınmış, bir kepçe muhallebi tepsiye dökülerek her tarafa eşit miktarda yayılması sağlanmıştır. Tepsi ocak üzerinde tutularak çevrile çevrile karışımın yanması sağlanmıştır.

Hindistan cevizi sütü çabuk yanan bir ürün olması sebebiyle karamelizasyon aşamasına ve süresine özen gösterilmiştir. Yakma işleminin ardından kalan muhallebi de tepsiye dökülmüştür. Kıvam 
alması için buzdolabında bekletilmiştir. Ürün sadece pirinç unuyla yapılabileceği gibi tercihe bağlı olarak mısır nişastasıyla da yapılabilir. Geliştirilen üründe pirinç unu ile mısır nişastası birlikte kullanılmıştır. Bunun nedeni ise üründe peltemsi bir yapı oluşturulmak istenmesidir. Araştırma sonucunda elde edilen ürünler Şekil 1'de gösterildiği gibidir.
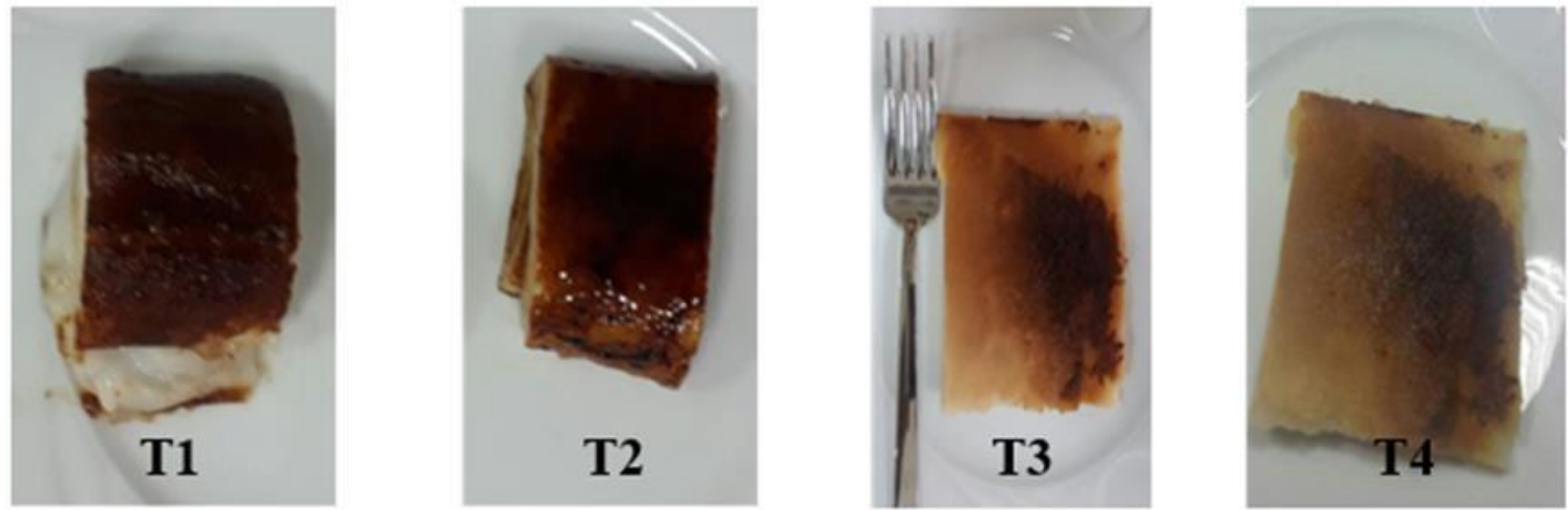

Şekil 1. Farklı Gramajlarla Elde Edilen Ürünler

\section{Verilerin Analizi}

Belirlenen amaçlar doğrultusunda elde edilen verilerin analizinde SPSS 22 programı yardımıyla betimsel istatistiklerden (yüzde, frekans) yararlanılmıştır. Araştırma kapsamında kullanılan tüketici beğeni ölçeğinin Cronbach's Alpha değeri 0,719 bulunmuştur.

\section{Bulgular}

Araştırmalar kapsamında yer alan eğitimli panelistlerin demografik özelliklerine ilişkin bilgiler Tablo 2'de gösterilmektedir.

Tablo 2. Eğitimli Panelistlerin Demografik Özellikleri

\begin{tabular}{lcc} 
& Frekans & Yüzde \% \\
\hline Cinsiyet & & \\
Erkek & 4 & 50 \\
Kadın & 4 & 50 \\
Eğitim Durumu & 8 & 100 \\
Lisansüstü & & \\
Yaş & 7 & 87,5 \\
$25-34$ & 1 & 12,5 \\
35 ve üzeri
\end{tabular}

Tablo 2'de görüldügü üzere panelistlerin cinsiyet dağılımları eşittir ve tamamı lisansüstü eğitim seviyesindedir. Katılımcılar arasında 25-34 yaş aralığında 7 kişi $(\% 87,5)$ bulunurken 1 kişi de 35 ve üzeri yaş aralığındadır. Eğitimli panelistlerin ürünlerle ilgili duyusal özellik yanıtları ise Tablo 3 'de ortalama olarak verilmiştir. 
Tablo 3. Eğitimli Panelistlerin Duyusal Analiz Bulguları

\begin{tabular}{|c|c|c|c|c|c|}
\hline & Duyusal Özellikler & T1 & T2 & T3 & $\mathbf{T 4}$ \\
\hline \multirow{4}{*}{ Görünüş } & İlk izlenim (çok kötü-çok iyi) & 2,875 & 3,00 & 3,375 & 4,00 \\
\hline & Muhallebinin rengi (çok açık-çok koyu) & 3,625 & 2,125 & 2,75 & 2,83 \\
\hline & Karamelizasyon (çok açık-çok koyu) & 4,00 & 2,375 & 1,75 & 3,08 \\
\hline & Şekil (bozuk-düzgün) & 3,00 & 3,00 & 4,375 & 4,08 \\
\hline \multirow{2}{*}{ Doku } & Homojenlik (homojen değil-homojen) & 4,25 & 4,25 & 4,125 & 4,375 \\
\hline & Ağızda sıvanan yapı (hiç yok- çok var) & 2,25 & 2,5 & 2,00 & 2,75 \\
\hline \multirow{2}{*}{ Koku } & Yanık kokusu (hiç yok-çok var) & 3,875 & 1,625 & 1,125 & 2,16 \\
\hline & $\begin{array}{l}\text { Hindistan cevizi kokusu (hiç yok-çok } \\
\text { var) }\end{array}$ & 1,625 & 2,25 & 2,5 & 2,875 \\
\hline \multirow{3}{*}{ Lezzet } & Damla sakızı (hiç yok- çok var) & 2,00 & 4,00 & 2,125 & 2,75 \\
\hline & Pirinç unu kokusu (hiç yok-çok var) & 1,5 & 1,875 & 2,00 & 1,33 \\
\hline & Nişasta kokusu (hiç yok-çok var) & & & 1,625 & 1,125 \\
\hline \multirow{7}{*}{ Kivam } & Hindistan cevizi (hiç yok-çok var) & 2,25 & 2,375 & 2,5 & 2,5 \\
\hline & Damla sakızı (hiç yok- çok var) & 1,75 & 4,00 & 3,625 & 3,875 \\
\hline & Pirinç unu (hiç yok- çok var) & 1,5 & 2,00 & 2,875 & 1,916 \\
\hline & Karamelizasyon oranı (hiç yok- çok var) & 4,125 & 1,625 & 2,00 & 3,16 \\
\hline & Tatlılık oranı (çok az-çok fazla) & 3,625 & 3,25 & 3,125 & 3,83 \\
\hline & Nişasta tadı (hiç yok- çok var) & & & 2,25 & 1,291 \\
\hline & Genel beğeni & 2,00 & 3,00 & 3,75 & 4,208 \\
\hline
\end{tabular}

Eğitimli panelistlerin alternatif tariflerle denenmiş kazandibinin görünüşü açısından değerlendirmelerine bakıldığında; ilk izlenim T1, T2, T3 ve T4 açısından uygun değerlere sahiptir. Muhallebinin rengi T1'de koyu olarak değerlendirilmiştir. Fakat T2, T3 ve T4'te ideal görünüme ulaşılmıştır. Karamelizasyon, T1'de çok koyu olarak gözlenmiştir. Bununla birlikte T4'te karamelizasyon rengi ideal koyuluğa ulaşmıştır. T1 ürününde karamelizasyonun koyu olmasının nedeni Hindistan cevizi sütünün çabuk yanma özelliğinden kaynaklanmıştır.

Diğer ürünlerde karamelizasyon süresi kısaltılarak devam edilmiştir. Şekil, dört üründe de düzgün olarak değerlendirilmiştir. Doku açısından incelendiğinde; bütün ürünlerde homojen bir yapı elde edilmiştir. Dört üründe de ağızda sıvanan yapının varlığı tespit edilmiştir. Koku açısından incelendiğinde; yanık kokusu T1'deki üründe yüksek olmakla birlikte T2 ve T3 ürünlerinde düsstüğü görülmüştür. Son yapılan T4 ürününde ise istenen yanık kokusu ortalamasına ulaşılmıştır. Hindistan cevizi kokusu T1 ürününde daha az algılanmıştır. Bunun nedeni yanık kokusunun fazla olmasıdır. T2, T3 ve T4 ürünlerinde Hindistan cevizi kokusunun arttığ1 görülmüştür. Damla sakızı kokusunun ortalamas1 T2 ürününde çok fazla olduğu görülmektedir.

Pirinç unu kokusu T4 ürününde en aza indirilmiştir. T1 ve T2 ürünlerde pirinç unu oranı daha fazla kullanılmıştır. $\mathrm{Bu}$ nedenle ürünlerde daha yoğun pirinç unu kokusu gözlemlenmiştir. T3 ve T4 ürünlerinde pirinç ununun gramajı düşürülerek pirinç unu kokusu en aza indirilmiştir. Nişasta ilk iki üründe hiç kullanılmamıştır. Sadece T3 ve T4 ürünlerinde kullanılan nişastanın kokusunun T3 ürününde daha fazla algılandığı görülmüştür. İlk iki üründe nişasta kullanılmadığında daha akışkan kıvama sahip bir ürün elde edilmiştir. Bu nedenle T3 ve T4 ürünlerinde nişasta ürüne eklenerek kıvamının daha koyu olması beklenmiştir. 
Lezzet açısından değerlendirildiğinde ise; Hindistan cevizi tadı dört üründe de istenen değerde gözlenmiştir. Damla sakızı tadı T2 ürününde çok fazla algılanmıştır. Yukarıda belirtildiği gibi damla sakızının ürüne başlangıçta eklenmesinden kaynaklanmaktadır. T3 ve T4 ürünlerinde damla sakızı ürüne sonradan eklenerek T2 ürünündeki değer düşürülmeye çalışılmıştır. Pirinç unu tadı T3 ürününde en yüksek ortalama olarak görülmüştür. Bu nedenle T4 ürününün de pirinç unu miktarı azaltılarak ortalaması düşürülmeye çalışılmıştır. Karamelizasyon tadının T1 ürününde algılanma oranı yüksektir. Bu nedenle karamelizasyon süresi kısaltılarak T4 ürününde ideal karamelizasyon tadına ulaşılmıştır.

Tatlılık oranına bakıldığında T1 ve T4 ürünlerinde tatlllık oranının yüksek olduğu görülmüştür. T1 ürününde daha az Hindistan cevizi sütü kullanıldığı için tatlılık oranı ön plana çıkmıştır. T4 ürününde süt oranı ile şeker oranını artırılmasından kaynaklı olarak tatlılık oranının yükseldiği düşünülmektedir. T2 ürününde daha az şeker tercih edilmiştir. T3 ürününde ise şeker oran1 artırılmasına rağmen daha fazla nişasta ve pirinç unu kullanıldığı için tatlılık oranı daha düşük çıkmıştır. Nişasta tadı T3 ürününde daha fazla algılanmakla birlikte T4 ürününde daha az algılanmıştır. Bu nedeni olarak T4 ürününde kullanılan nişasta gramajının T3 ürününe göre daha az olması gösterilebilir. Kıvam açısından değerlendirildiğinde bütün ürünlerin ideal kıvamda olduğu görülmüştür. Genel beğeni olarak T1 ürününde genel beğeni ortalamasının düşük olduğu görülmüştür. Reçetedeki gramajlarda değişiklik yapılarak T4 ürününde istenilen genel beğeni düzeyine ulaşılmıştır.

\section{Standart Tarif Oluşturulması}

Veganların ve çölyak hastalarının tüketimine uygun formlarda hazırlanan kazandibilerin duyusal analizi yapıldıktan sonra en çok beğenilen reçete yapılarak standart reçete oluşturulmuştur. Oluşturulan bu reçete için 85 tüketici üzerinde bir duyusal analiz yapılmıştır ve ölçek soruları 5'li likert tipte "Hiç Beğenmedim (1) - Çok Beğendim (5)" şeklinde sorulmuştur. Ayrıca tüketicilerin satın alma niyetleri de ölçülmüştür. Duyusal analizin yapıldığı tüketici grubuna ilişkin demografik özellikler Tablo 4'te gösterilmektedir.

Tablo 4. Tüketicilerin Demografik Özellikleri

\begin{tabular}{lll} 
& Frekans & Yüzde \% \\
\hline Cinsiyet & & \\
Erkek & 46 & 54,1 \\
Kadın & 39 & 45,9 \\
Eğitim Durumu & & \\
Ön Lisans & 5 & 5,9 \\
Lisans & 75 & 88,2 \\
Lisansüstü & 5 & 5,9 \\
Yas & & \\
$18-24$ & 81 & 95,3 \\
$25-34$ & 4 & 4,7 \\
\hline
\end{tabular}

Tablo 4'de görüldügü üzere erkekler $\% 54,1$ oranında çoğunluğu oluştururken, kadınların \%45,9 olduğu görülmektedir. Yaş açısından değerlendirildiğinde çoğunluğu 18-24 yaş aralığından oluşurken eğitim durumlarında çoğunun lisans mezunu olduğu görülmektedir.

Tüketicilerin standart tarifle yapılan kazandibi tatlısına ilişkin duyusal özellik, genel beğeni ve satın alma niyeti düzeyleri Tablo 5 'te yer almaktadır. 
Tablo 5. Tüketicilerin Duyusal Analiz ve Satın Alma Niyeti Bulguları

\begin{tabular}{lcc} 
& Duyusal Özellikler & Ortalama \\
\hline Görünüsş & 4,17 \\
Lezzet & 4,40 \\
Doku & 4,21 \\
Koku & 4,49 \\
Genel Beğeni Düzeyi & 4,28 \\
Satın Alma Niyeti & 4,07 \\
\hline
\end{tabular}

Tüketicilerin kazandibi tatlısının görünüşe yönelik ortalamalarının 4,17 olduğu görülmektedir. Lezzet, doku ve koku özelliklerinin ortalamalarının da 4 değerinin üzerinde olduğu tespit edilmiştir. Koku özelliğinin en yüksek ortalamaya $(4,49)$ sahip olduğu görülmektedir ve tatlının genel beğeni düzeyi 4,28 olarak belirlenmiştir. Ayrıca tüketicilerin söz konusu tarifle yapılan tatlıyı satın alma niyetinde $(4,07)$ olduğu sonucuna varılmıştır.

\section{Sonuç ve Öneriler}

Dünyada 1 milyardan fazla insan her sene turizm hareketliliğine katılmaktadır. Turizm hareketliliğine katılan turistlerin içinde belli bir oranda vejetaryen ya da vegan beslenmeyi tercih etmiş turistler de bulunmaktadır. Vejetaryen ve vegan turistler, yaşam felsefelerindeki tercihlerinden dolayı çoğunluk için üretilmiş olan mal ve hizmetleri tüketmemektedir (Vatan ve Türkbaş, 2018). Dolayısılyla alternatif yemekler araştırmakta ve yeni vagan yemekler ile tanışmaktadırlar (Yı1maz, 2018). Çölyak hastaları için ise üretilen unlu mamullerin kalitesinin düşük olması görüşü, araştırmacıları duyusal özellikleri ve kabul edilebilirliği daha yüksek olan yeni ürünler üretmeye yönlendirmiştir (Hayıt ve Gül, 2017). Dolayısıyla bu çalışmada çölyak hastalarına ve vegan bireylere yönelik ürün geliştirilmeye çalışılmıştır. Bu kapsamda da veganların ve çölyak hastalarının tüketebileceği formatta kazandibi tatlısı hazırlamış ve standart reçete oluşturulmuştur.

Reçetelerde farklı miktarlarda Hindistan cevizi sütü, damla sakızı, şeker, mısır nişastası ve pirinç unu kullanılarak 4 ürün üretilmiştir. Söz konusu ürünler içerisinde T1 koduyla ifade edilen kazandibi tatlısının en düşük beğeni düzeyine sahip olduğu görülmüştür. Ancak 1 lt Hindistan cevizi sütü, 1 adet damla sakızı, 200 gr şeker, 40 gr mısır nişastası, 60 gr pirinç ununun kullanıldığı tarif eğitimli panelistler tarafindan en çok beğenilen reçete olmuştur. Benzer şekilde Seferoğlu (2012) çalışmasında çölyak hastalarına yönelik kestane unu ve glütensiz un kullanarak ekmek, kek ve bisküvi çeşitleri üreterek duyusal analizi yapmıştır ve sonuç olarak kestane unu ile yapılan ürünlerin beğenildiği sonucuna varmıştır. Ergin (2011) de çalışmasında çeşitli un ve nişasta ham maddeleri kullanarak glütensiz bisküvi, erişte ve pide üreterek öğrenci ve öğretim üyelerinden oluşan panelistler üzerinde duyusal analiz yapmıştır ve katılımcıların genel itibariyle memnun kaldıklarını belirtmiştir. Son yıllarda da glütensiz ürün geliştirmek amacıyla yapılan farklı çalışmalara rastlamak mümkündür (Yalçın ve Başman, 2006; Gambuś, Gambuś, Pastuszka, Wrona, Ziobro, Sabat, Mickowska, Nowotna ve Sikora 2009). Ayrıca bu tarif, standart reçete şeklinde tekrar yapılarak 85 tüketici üzerinde duyusal analizi yapılmıştır ve bütün katılımcıların beğendikleri sonucuna varılmıştır. Tüketicilerin söz konusu reçete ile yapılan tatlıyı da satın alma niyetinde oldukları tespit edilmiştir.

Vegan beslenme modelini uygulayan bireylerin ya da çölyak hastalarının tüketimi amacıyla geliştirilen kazandibi aslında tüm bireylerin haz alarak tüketebilecekleri bir tatl formunda olduğu yapılan çalışma sonucunda görülmektedir. Dolayısıyla geleneksel Türk mutfağg sütlü tatlılarından biri olan kazandibini geliştirilerek tüketim alanının ve miktarının arttırılması mümkün olabilir. Ayrıca gastronomi turizmi kapsamında Türk mutfağının gelişim göstermesine katkı sağlanması için farklı tatlılar özel tüketim alışkanlıklarına yönelik formlarda hazırlanarak tüketime sunulması 
önerilmektedir. Bu kapsamda geliştirilen ürünlerin yiyecek-içecek işletmelerinin menülerine eklenmesi sağlanabilir.

\section{Kaynakça}

Aksürmeli, Z. S. T., \& Beşirli, H. Vegan Kimliğin Oluşumu: Vegan Olmak Ve Vegan Kalmak. Akademik Hassasiyetler, 6(12), 223-249.

Albayrak, A. (2017). Restoran İşletmelerinin Yenilik Uygulama Durumları: İstanbul'daki Birinci Sınıf Restoranlar Üzerine Bir Çalışma. Journal of Tourism and Gastronomy Studies, 53, 73.

Dilek, S. E. (2018). Türkiye'de Vejetaryen/Vegan Oteller Mümkün Mü? Kavramsal Bir Tartı̧̧ma. Dokuz Eylül Üniversitesi İşletme Fakültesi Dergisi, 19(1), 1-18.

Durlu-Özkaya, F., Akbulut, B. A., \& Tulga, D. (2017). Gastronomi Turizmi Engelleri Kapsamında Çölyak. Karadeniz Sosyal Bilimler Dergisi, 9(16), 213-228.

Ergin, A. (2011). Çölyak Hastalarına Özel Bisküvi, Erişte ve Pide Üretimi. (Yayımlanmamış Yüksek Lisans Tezi), Pamukkale Üniversitesi Fen Bilimleri Enstitüsü, Gıda Mühendisliği Ana Bilim Dalı, Denizli.

Gambuś, H., Gambuś, F., Pastuszka, D., Wrona, P., Ziobro, R., Sabat, R., Mickowska, B., Nowotna A. \& Sikora, M. (2009). Quality of gluten-free supplemented cakes and biscuits. International Journal of Food Sciences and Nutrition, 60(sup4), 31-50.

Hayıt, F., \& Hülya, G. Ü. L. (2017). Çölyak ve Çölyak Hastaları İçin Üretilen Ekmeklerin Kalite Özellikleri. Iğdır Üniversitesi Fen Bilimleri Enstitüsü Dergisi, 7(1), 163-169.

https://tvd.org.tr/2015/10/tanimlar/ (Erişim Tarihi: 12.02.2020.)

https://www.medicalpark.com.tr/colyak-hastaligi-nedir-belirtileri-ve-tedavi-yontemleri-nelerdir/hg-1948 (Erişim Tarihi: 12.02.2020.)

Olgun, M., Başçiftçi, Z. B., Ayter, N. G., \& Aydın, D. (2017). Farklı Özellikteki Ekmeklik Çeşitlerinin Duyusal Analizler Yönünden Değerlendirilmesi. Ziraat Fakültesi Dergisi, 12(2), 47-54.

Savtekin, N. (2014). Çölyak Hastaları İçin Baklagil Unları İle Zenginleştirilmiş Mısır Eriştesi. (Yayınlanmamış Yüksek Lisans Tezi). Hacettepe Üniversitesi, Fen Bilimleri Enstitüsü, Gıda Mühendisliği Ana Bilim Dalı, Ankara.

Seferoğlu, B. (2012). Çölyak Hastalarına Yönelik Kestane Unu ve Glütensiz Unlarla Hazırlanan Ekmek, Kek ve Bisküvi Çeşitlerinin Duyusal Analiz İle Değerlendirilmesi. (Yayımlanmamış Yüksek Lisans Tezi). Hacettepe Üniversitesi, Sağlık Bilimleri Enstitüsü, Beslenme ve Diyetetik Ana Bilim Dalı, Ankara.

Vatan, A., \& Türkbaş, S. (2018). Vejetaryen Turist ve Vegan Turist Kimdir?(Who is Vegetarian Tourist and Vegan Tourist?). Journal of Tourism and Gastronomy Studies, 24, 39.

Yalçın, S., \& Başman, A. (2006). Glutensiz Makarna ve Erişte Üretimi. Türkiye 9. Gıda Kongresi. 637-640.

Yıldız, Ö. (2018). Yiyecek, Kültür ve Turizm İlişkisi. A. Akbaba ve N. Çetinkaya içinde Gastronomi ve Yiyecek Tarihi (s. 125-137) Ankara: Detay Yayıncilik.

Yılmaz, A. B. (2018). Yeni Medya ve Toplumsal Hareketler: Vegan Hareketi Örneği Üzerine Bir İnceleme. (Yayınlanmamış Yüksek lisans tezi). İstanbul Ticaret Üniversitesi, Sosyal Bilimler Enstitüsü, Medya ve İletişim Sistemleri Ana Bilim Dalı, İstanbul.

Yönal, O., \& Özdil, S. (2014). Çölyak Hastalığı. Güncel Gastroentoloji, 18(1), 93-100. 